\title{
Disparate Treatment and Disparate Impact: A Tale of Two Burdens
}

\author{
C. Ray Gullett \\ The University of Texas at Tyler \\ Tyler, Texas
}

"It was the best of times, it was the worst of times ...." These famous words from Charles Dickens' A Tale of Two Cities may describe rather well the current situation with regard to fair employment practice compliance. In its widely discussed decision, Watson v. Ft. Worth Bank \& Trust [7], the Supreme Court has both clarified and made more confusing the legal grounds on which employees and applicants can challenge hiring and promotion decisions and the bases on which employers can defend themselves. It is the purpose of this discussion to identify the crucial issues at stake in the case and to interpret their meaning for employees and employers alike. As will be seen, what we do not yet know is as important as what we do know.

\section{Disparate Treatment $v$. Disparate Impact}

To understand the case and its implications, we should briefly review the two legal paths that may be taken when an employment discrimination claim is filed in the federal courts. If an individual believes he or she has been denied a job or turned down for promotion for discriminatory reasons, a charge may be filed under the legal doctrine set forth by the Court in McDonnell Douglas v. Green [4]. This type of case is known as one of disparate treatment.

In a disparate treatment situation, the plaintiff's burden is to show that the employer intentionally discriminated against him or her because of race, sex, or some other reason prohibited by equal employment laws. To meet this burden, the plaintiff must first show that he or she made application for the job, was then rejected for that job, and that the employer continued looking for someone with the rejected applicant's qualifications [4]. If this can be shown, the employer must put forth a justifiable business reason for the decision. In other words, the employer must convince the court that it had no intention to discriminate.

It is very important to note that the employer does not have to prove that its reason for rejection is objectively related to job success; its only obligation is to show that it used some reason other that a discriminatory one for the decision. Finally, the plaintiff has one more chance to produce evidence that the reason given was nothing more than a pretext (a trumped up excuse) for discrimination. As many well-publicized cases have shown [6], the employer's burden is much lighter than the plaintiff's unless there has been a history of discrimination in the organization. Proving intentional discrimination is often a difficult task [7].

Journal of Business Strategies, Volume 6, Number 1 (Spring 1989) 
By contrast, a disparate impact discrimination charge disregards employer motive or intent. Instead, the focus is on the effect of a selection practice upon a protected group. In its famous Griggs v. Duke Power Co. case [2], the Supreme Court ruled that a selection device which appears to be neutral and objective may still illegally discriminate in practice. If a disproportionate number of persons from a protected group are screened out as a result of its use, the employer has the burden of proving that the selection device validly predicts success on the job [3]. Satisfying this validity requirement is a much more demanding task than is refuting a charge of intentional discrimination [1]. Figure 1 is a summary of these two discrimination theories.

\section{Figure 1}

\section{Burdens for Each Side in Disparate} Treatment and Disparate Impact Cases

(1)

Aggrieved Person(s) Must

First Show

Disparate Treatment

1. Application was made for a position for which he or she was qualified

2. Rejection was for reasons that raise an inference of discrimination

3. Employer continued to search for others with similar qualifications

Disparate Impact

Show a significant statistical imbalance in the employer's workforce that suggests discrimination caused by an apparently neutral and objective method
(2)

Employer Must

Then

Provide some legitimate, non-discriminatory reason Show that the employ er's reasons were a pretext
(3)

Aggrieved Person(s)

Must Then

As a result of these difficulties, it is not surprising that more claims are filed under the disparate impact theory of discrimination than under disparate treatment. If an initial (or prima facie) case of discrimination can be shown using the disparate impact approach, the employer is likely to have a much more difficult time defeating the charge.

But herein lies the difficulty for many aggricved employees or applicants. The Supreme Court's disparate impact rulings have dealt only with "objective" measurement techniques such as standardized tests and height and weight requirements $([1],[2])$.

Thus, while not totally unified on the subject, lower courts have required that two criteria be met before a case could proceed under the disparate inpact approach: A 
class of protected workers must claim to have been disproportionately screened out, and the selection or other decision making device must be objective and neutral on its face. A promotion system based on managerial judgment could thus be challenged only under disparate treatment theory. Although discrimination could still be proved by the plaintiff(s), the employer's burden of proof would be much lighter that in a disparate impact case. This apparent inequity sets the stage for the issues discussed by the Court in Watson.

\section{Watson v. Ft. Worth Bank and Trust}

The central issue in this case was the following: Can a subjective promotion decision system be attacked under disparate impact analysis? In brief, the Court unanimously said "yes," broadening the basis for a prima facie case of disparate impact. With all eight justices concurring (Justice Kennedy had not yet joined the Court), Justice O'Connor instructed the Court of Appeals to determine if statistical evidence was sufficient to pursue a charge of disparate impact discrimination in this case [7].

If the Court's opinion had stopped at this point, one could conclude that persons charging discrimination in employment practices had won a major victory in pursuit of their rights. The burden of proof for employers in many cases would be much heavier.

But four of the justices went much furthet. Although they were only a plurality (three of the remaining four dissented and one refused to address this issue), they re-framed the burden of proof for employers in all disparate impact cases. It is also important to note that their comments were not a part of the formal ruling in the case. The comments were included as dicta (instructions) to lower courts in dealing with future rases. These instructions were a response to arguments made against the use of disparate impact analysis in situations where employers use subjective factors in their decision making process.

Essentially, Justice O'Connor and her three concurring colleagues stated that the employer's burden of proof is not as rigorous as some may have thought. In summary form, the "new" interpretation of disparate impact claims is as follows:

1. Not only must the plaintiff show a statistical imbalance in the workforce, but it must also identify which of the steps in the decision making proccss has supposedly caused the imbalance. For subjective selection or promotion steps, this may be particularly difficult.

2. Where a statistical imbalance does occur, it must be strong enough to suggest a cause and effect. Here the justices would commit to no standard, but as in the past, they stated that the difference must be "substantial." They also reaffirmed employers' rights to challenge any deficiencies in the statistics.

3. The ultimate burden of proving that an employer has discriminated against a protected group always remains with the plaintiff. This is a major departure 
from earlier cases. Here, the justices stated that formal "validation studies" are not required even in standardized or objective tests. Instead, the employer must put forth a "legitimate business purpose" for the use of a selection or employment decision making device. If taken literally, this statement substantially lightens the burden on employers to justify their employment decisions. As one dissenting justice commented, "the echo from the disparate treatment cases is unmistakable" [7]. Figure 2 summarizes these points.

\section{Figure 2}

New Interpretation of

Disparate Impact Cases

(1)

Aggrieved Person(s) Must

First Show

1. Show a statistical imbalance in the workforce which suggests discrimination

2. Identify the specific employment practice of practices causing the discrimination
(2)

Employer Must

Then

Provide a legitimate, non-discriminatory reason for the use of the employment practice
(3)

Aggrieved Person(s) Must Then Identify an alternative, but job-related selection device which will have less disparate impact

\section{Implications with Suggestions for Employers}

In sum, the Court has unanimously agreed that employees have the right to use the disparate impact theory to challenge personnel decisions which are subjective or judgmental in nature. This ruling broadens the basis on which such decisions may be attacked and would appear to be a victory for those who see themselves as victims of discrimination. Employers are now more vulnerable to legal challenges of subjective employment decisions.

But the added comments of four justices regarding standards of evidence and burden of proof in such cases may ultimately strengthen employers' defenses against any sort of disparate impact charge. It is very important to note that a fifth justice must concur on a case directly dealing with these two issues before firm conclusions can be drawn. If indeed this occurs, employment discrimination law may be affected more significantly than at any time since the early 1970s.

Given the somewhat contradictory but nevertheless significant impact of the Watson case, several suggestions can be provided for employers for staying within equal employment guidelines. It should be noted that these comments are not intended to take the place of legal advice and should not be regarded as such. They do, however, draw upon sound personnel practices in the equal employment setting. 


\section{Avoid Obviously Discriminatory Employment Decisions}

As in the past, employers must be careful to avoid selection or other employment practices which clearly exclude an individual because of employer prejudice. An employer who can be shown to have deliberately discriminated against persons for such reasons as race, sex, age, or other protected categories can be successfully prosecuted. "Men's jobs" or "women's jobs" can, for example, rarely be defended successfully. Questions or comments about an applicant's or employee's age, race, or national origin make a negative employment decision difficult to defend.

\section{Carefully Scrutinize Subjective Employment Criteria}

Now more than ever, the use of subjective bases such as supervisory judgment for employment decisions deserves careful attention by management. The Supreme Court has not prohibited these decision techniques, but they are now more vulnerable to an initial court challenge.

Before Watson the person or persons claiming discrimination were required to show discriminatory intent of the kind noted in the previous section. Now, such challenges may also be made on the basis of discriminatory impact or effect. By presenting statistical proof acceptable to the court, plaintiffs can make a case for discrimination which an employer must then disprove. To avoid such charges, employers should carefully examine the impact of their subjective employment practices. Where such practices result in a disproportionate rejection of protected groups, they are targets for challenge.

Since the Watson case has made unclear what a successful employer defense of an impact charge must be, it would be wise to follow past rulings until additional directions are given by the Court. Thus the employer's burden is still one of showing the "business necessity" of any employment practice challenged under the disparate impact doctrine. Typically, this means showing either statistical validity or content validity of the offending employment procedure. Since subjective decisions do not lend themselves to statistical validation, a content validity approach is most practical.

Essentially, content validity is based on the idea that the decision making tool is logically related to the person's future success. For example, a supervisor's evaluation of an applicant in an interview would be much more defensible if an up-to-date job description has been done and a standardized rating form is used to evaluate the characteristics believed necessary for successful job performance. While the interviewer's impressions are still somewhat subjective, they are more structured and thus more defensibly valid than a simple "pass - fail" approach based on intuitive reasoning. Subjective decision making tools may thus become more acceptable to a court and also more efficient in personnel decisions regardless of legal challenge.

\section{Do Not Abandon Current Validation Techniques for "Objective" Selection Techniques}

Employers who have developed validation studies (either statistical or content) for objective selection devices such as standardized tests should continue to monitor and update them. Although the Supreme Court's plurality suggested that these studies 
may be less important in the future, this is not a settled issue. Until further clarification is provided, employers should assume that such studies will continue to be needed in defense of disparate impact charges.

Keep a Close Watch on Further Court Rulings

Both employers and employees should carefully watch for additional direction form the Supreme Court concerning discrimination in employment. All that can be said with assurance now is that those who claim unfair treatment have a broader basis on which to make that claim.

There is also a strong suggestion that employers may have a less difficult burden of defending against such charges than in the past. Only time and future clarification by the Court can determine this highly important issue.

\section{References}

1. Albemarle Paper Company v. Moody, 422 U.S. 405, 10 FEP 1181 (1975).

2. Griggs v. Duke Power Company, 401 U.S. 424, 3 FEP 175 (1971).

3. Hazelwood School District v. United States, 433 U.S. 299, 15 FEP 1 (1977).

4. McDonnell Douglas Corp. V. Green, 411 U.S. 792, 5 FEP 965 (1973).

5. Teamsters v. United States, 431 U.S. 324, 14 FEP 1514 (1977).

6. Texas Department of Community Afajrs v. Burdine, 450 U.S. 248, 25 FEP 113 (1981).

7. Watson v. Fort Worth Bank \& Trust, No. 86-6139, U.S. Supreme Court (6/29/88, Bureau of National Affairs). 